\title{
PANAMA'S INTERNATIONAL BANKING CENTER
}

\author{
The Direct Employment Effects* \\ Donald R. LESSARD \\ Massachusetts Institute of Technology, Cambridge, MA 02139, Ir \\ Adrian E. TSCHOEGL \\ University of Michigan, Ann Arbor, MI 48109, USA
}

Received May 1986, final version received December 1986

\begin{abstract}
Despite the political saliency of employment, the growing scholarly literature on financial centers contains only a few cursory estimates of employment in international banking. We use simple methods to calculate the total and marginal direct employment effects of Panama's International Banking Center. The results, which appear reasonable, suggest that international banking activities are not very labor intensive and provide even fewer jobs than many observers infer from the relatively impressive asset amounts involved.
\end{abstract}

\section{Introduction}

The extent of benefits to hosting an international banking center interests the governments of countries such as India and Australia, which have considered or are considering the establishment of offshore banking centers [see Bhattacharya (1982) and Whitlam et al. (1984), respectively]. The employment effects are not necessarily the only, or even the most important effects of an international banking center on the host economy. We have, in fast, dealt with many of the issues elsewhere [Lessard and Tschoegl (1985)].

However, employment is often the first concern of policymakers. Employinent effects figured in the discussion of the desirability of permitting International Banking Facilities (IBFs) in New York [Trivoli (1981)]. They

*This paper was prepared in connection with a report on Panama's International Banking Center under the auspices of USAID technical assistance project to the Panamanian Ministry of Planning and Economic Policy (MIPPE). The conclusions are the authors' sole responsibility and do not necessarily reflest the views of the project sponsors, MIPPE, the National Banking Commission, or the authors' universities. We would like to thank Kevin Harrington of the National Banking Commission for providing the data, and Pedro Videla and Chwo Min Yu for able research assistance. We would also like to thank Carlene Francis for helpful comments on an earlier draft, and the reviewer of this journal whose detailed suggestions have improved the paper. 
are also of some soncern to the Government of Panama which is evaluating the contribution of iuv international banking center to the domestic economy.

Despite the political saliency of employment, the growing scholarly literature on financial centers contains only a few cursory estimates of employment effects [e.g., Francis (1985)]. Using data from the late 1960s and early 1970s, Johnson (1976) found a negligible direct employment effect of international banking activities in Panama. At that time, however, the new banking law (see below) had been in place for only a short time, so that foreign banks had had little time to react to the opportunities it had created. Bhattacharya (1980), using data from 1974-1976, discussed the issue of employment in passing, but made no estimates and concurred with Johnson. Therefore, this note investigates the employment consequences of growth in international loans and deposits in recent years.

There is good reason, ex ante, to believe that this growth has not had much of an effect on employment. McCarthy (1979) in his survey of the benefits and costs of offshore banking centers generally found slight effects on employment. Much of the loans and deposits in Panama represent simple booking for tax and administrative purposes of transactions effected elsewhere. Furthermore, the amounts per transaction are typically large; to the degree that employment is related to the number of transactions, again it will not be large.

The methods we use to calculate the direct employment effects of Panama's International Banking Center are simple due to data limitations. Even so the results, which appear reasonable, suggest that international banking activities are not very labor intensive and provide fewer jobs than the relatively impressive total dollar amounts might imply.

Section 2 below describes developments in the International Banking Center. Section 3 gives our estimates of total and marginal employment effects. Section 4 estimates the U.S. dollar value of the Panamanian employment in 1983 generated in the Center. The last section is a summary.

\section{Development of the banking system}

The key event in the recent development of the banking system in Panama is Cabinet Decree No. 238 (1970) which reformed the banking system and established the National Banking Cormmission. The commission issues three classes of banking licenses - general, international, and representative office. General licenses permit foreign and domestic banks to do business with both Panamanian residents and non-residents. International licenses confine the holders essentially to transactions with non-residents. A representative office can engage only in liaison and market intelligence activities for its parent as it does not maintain any books and hence cannot take deposits or make loans. 
The number of private domestic banks (i.e., those for which the Banking Commission gives Panama as the country of origin) increased from two in 1970 to 12 in 1983. All have general licenses, except for one from 1980 which has an international license. Over the perioc there have also been two government owned domestic banks. The number of foreign banks with general and international licenses has increased from 15 and three, respectively, in 1970 to 56 and 40 in 1983. At the same time, the number of representative offices has risen from one to 11 .

Between 1970 and 1983, domestic loans and deposits grew from U.S.\$979 and U.S.\$794 million (in constant 1983 dollars using the U.S. Consumer Price Index), to U.S.\$3,533 and U.S.\$3,365 million, respectively. International (offshore) loans and deposits grew from U.S.\$571 and U.S.\$958 million to U.S.\$18,647 and U.S.\$26,548 million in 1982, and then fell back to U.S.\$14,834 and U.S.\$22,694 million in 1983.

Employment in the banking system grew from 2,881 employees in 1970 , to 8,996 in 1983. In 1983, 266 of these persons were expatriates.

While total banking system assets are in the order of U.S.\$40 billion, international interbank deposits account for about a quarter of this amount. Foreign banks hold over 94 percent of total assets because of their domination of the internationa! activity. In fact, international loans and deposits are almost exclusively in the hands of the foreign banks.

Focusing on domestic loans and deposits, the foreign banks' share is lower, as one would expect. Foreign banks with general licenses account for some 63 percent of domestic loans and deposits. Among the domestic barks, the two government owred banks account for the bulk of the loans and deposits.

As one would expect, the growth rate of loans has essentially paralleled that of deposits in the domestic and international markets, with the rate of growth of international activities being two to three times that of domestic ones. The rate of growth of the balance sheet items has exceeded that of employment in banking, which could indicate some productivity gains in the banking sector.

The banking system has done well over the period. First, domestic loans and deposits have grown more rapidly than GDP (gross domestic product), indicating financial deepening. Second, employment in the banking sector has grown more rapidly than employment in Panama in general. Third, the rate of growth of international loans and deposits has exceeded that of the worldwide rate of growth of gross Eurocurrency liabilities, indicating an increasing relative importance for Panama, on average, in the offshore arena.

As far as international banking is concerned though, Panama's situation has changed recently. International loans and deposits fell 20.4 and 14.5 percent, respectively, in real terms in Panama from 1982 to 1983, while real gross Eurocurrency liabilities increased a marginal 2.24 percent over the period. Thus Panama appears to have lost some ground, relative to the other 
offshore centers in general. This is due to two factors. One is the Latin American debt crisis, particularly after August 1982, which has resulted in reduced lending to Latin America and reduced deposit flows from it. The other factor is the growth of IBFs after their authorization in December 1981 which has resulted in the transfer of some deposits to the U.S.

\section{Statistical estimates}

To estimate the total employment attributable to international banking activity we use an approach almost identical to Johnson's (1976). Our data consists of the total international assets of the general and international license banks, and the total number of employees in the latter.

We then make a number of simplifying assumptions. First, we use international assets, which account for over 99 percent of the assets of international license banks, as a measure of international activity. Second, we apply the international license banks' ratio of employees to international assets to the general license banks on the grounds that general license banks engage in the same international activities as international banks and have access to the same technology. Table 1 presents the results for 1980-1984.

Table 1

Employment in international banking in Panama."

\begin{tabular}{lrrrr}
\hline & 1980 & 1981 & 1982 & 1983 \\
\hline $\begin{array}{l}\text { Inter,iational assets } \\
\text { (1) General license }\end{array}$ & 19,039 & 24,728 & 27,143 & 24,813 \\
(2) International license & 15,325 & 16,533 & 16,465 & 12,736 \\
& & & & \\
$\begin{array}{l}\text { Panamanian employment } \\
\text { (By bank license) }\end{array}$ & & & & \\
(3) Representative & 19 & 17 & 15 & 12 \\
(4) International & 374 & 446 & 502 & 481 \\
(5) General & 465 & 667 & 828 & 937 \\
Total & 858 & 1,130 & 1,345 & 1,430 \\
& & & & \\
Fureign employment & & & & \\
(By bank license) & & & & \\
(6) Representative & 7 & 5 & 4 & 4 \\
(7) International & 51 & 58 & 67 & 71 \\
(8) General & & 87 & 110 & 138 \\
Tijal & 121 & 150 & 181 & 213 \\
\hline
\end{tabular}

aSource: National Banking Commission.

IIn current U.S.S millions.

Row $5=$ Row $(4)^{*}$ Row (1)/Row $(2)$.

dRow $8=\operatorname{Row}(7)^{*}$ Row (1)/Row (2). 
International banking activity provided employment for about 1,430 Panamanians in 1983, representing about 16.4 percent of total Panamanian employment in banking. This contrasts with the fact that international assets accounted for $\mathbf{8 7 . 6}$ percent of total banking system assets in 1983. The figures for total employment in Panama in 1982 suggest that international banking represented about 0.3 percent of this amount.

We pursise two avenues to estimate the marginal employment effects: a time series approach and a cross-sectional one. First, utilizing data for 19651983, we regress the natural logarithm of employment in each year on the natural logarithms of domestic and international loans and deposits in each year. The coefficients then give the elasticities of employment with respect to the independent variables. The results are (with $t$-statistics in parentheses),

$$
\begin{gathered}
\ln E(t)=3.68+0.05 \ln R I L(t)+0.03 \ln R I D(t) \\
(3.74)(0.51) \\
+0.12 \ln R D L(t)+0.44 \ln R D D(t) \\
(0.56) \quad(4.18) \\
R^{2}=0.98, S E=0.08, F=226.29, D W=0.94
\end{gathered}
$$

$R I L$ and $R I D$ represent real international loans and deposits respectively, and $R D L$ and $R D D$ the domestic equivalents. Correcting for the evident serial correlation via Durbin's method gives a serial correlation coefficient of 0.28 , but has a negligible effect on the magnitudes and significance of the coefficients.

Clearly then, the elasticities of employment with respect to international loans are both negligible in magnitude and statistically not significantly different from zero. In fact, dropping the first three independent variables has almost no effect on the fit of the equation.

Nevertheless, because we are interested in estimation rather than hypothesis testing, we can use the equation to estimate the change in the number of jobs which would accompany a U.S.\$1 billion change in international deposits, accompanied by a commensurate change in international loens. Using the data for 1983, this would suggest that U.S.\$1 billion would translate into 31.7 employees. Casting this number backwards would further suggest that the fall in international deposits between 1982 and 1983 cost about 120 jobs.

For the cross-sectional approach we use a simple model [Kaufman (1970), Short $(1971,1977)$ and Cho: and Tschoegl $(1984)]$. In order so comply with Panama's law on bank secrecy, the National Banking Commission provided the necessary data for a month around December 1983, in a manner designed to conceal the banks' names. Regressing employment in each bank 
in Panama on its Panamanian domestic and international assets and number of offices gives these results (with $t$-statistics in parentheses),

$$
\begin{aligned}
& \ln E(i)=1.63+0.34 \ln D A(i)+0.12 \ln I A(i)+0.81 \ln B R(i) \\
& \quad(8.74)(8.75) \\
& R^{2}=0.73, S E=0.78, F=94.25
\end{aligned}
$$

where $E(i)$ is employment in the ith bank, $D A(i)$ and $I A(i)$ represent its domestic and international assets respectively, and $B R(i)$ the number of offices, includin $n_{6}$ the head office in the case of domestic banks.

Evaluating eq. (2) at the mean values for international assets (U.S.\$307.63 million) and employment ( 80.71 persons), indicates that a U.S.\$1 billion change in a bank's international asset would result in a change of 31.5 jobs in that bank. In 1983 the ratio of foreigners to Panamanians in international activities was 1:6.71. This suggests that for every 31 positions, 4 jobs for foreigners would accompany every 27 jobs for Panamanians.

\section{Dollar value of employment}

Panama's official currency, the Balboa, is linked to the U.S. dollar (the exchange rate is 1:1). The dollar is legal tender in Panama, furnishing most of Panama's circulating medium.

The employment international banking provides is relatively well paid. In 1983 , the average annual salary per Pnamanian employee was $\$ 5,722$ in the official banks, $\$ 10,187$ in the private general license banks, and $\$ 10,807$ in the international and representative license banks. Presumably the higher private sector salaries represent compensation for the greater risk of unemployment, and the fact that most of their employees are not in the provinces but rather in Panama City, which is a higher cost-of-living area. Even so, one can probably attribute part of the differential to the greater skill intensity of international banking activities.

We can use the 1983 figure of 1,430 jobs and an average annual salary of U.S. $\$ 10,807$ per person to estimate an approximate lower bound for the peyroll contribution of international activities of U.S. $\$ 15.5$ million or 0.8 percent of GDP. If we add in the 213 foreign employees at an average wage of $\$ 25,282$ per person, the upper bound becomes U.S.\$20.6 million, or 1.1 percent of GDP.

\section{Conclusion}

We have used relativaly simple methods to estimate the number of employees and their income originating from Panama's International Banking 
Center. Even so, the results are quite reasonable. They suggest that international activities contributed some 1,430 jobs for Panamanians in 1983, compared with the 60-70 which Johnson (1976) estimated for 1970. At the margin, a $\$ 1$ billion change in international assets is associated with a change of about 27 jobs for Panamanians. Furthermore, employees engaged in international banking appear to earn a higher average salary.

In the context of the total Panamanian economy, the contribution of international banking center to employment is limited. First, without the benefit of the 1970 decree, some trade-related international banking activities would still take place and generate employment. Second, the number of jobs is small relative to total employment in Panama (about 0.3 percent using 1982 employment data). Third, as efficiency increases over time, the marginal effect will fall. Fourth, employee income represents only about 1 percent of GDP. Nevertheless, the contribution is welcome to a country which suffers from high unemployment.

The results suggest that only small countries with low per capita incomes will find creating an international banking center of value from the point of view of employment effects. This is consistent with the fact that aimost all such centers are in small, developing countries, and supports the position of those commentators [e.g., Chrystal (1984)] who remarked that the creation of international banking facilities in the United States would have a negligible employment effect for New York City.

\section{References}

Bhattacharya, A.K., 1980, Offshore banking in the Caribiean by U.S. commercial banks, Journal of International Business Studies 11, no. 3, 37-46.

Bhattacharya, A.K., 1982, Offshore banking costs and benefits, in: Phillip D. Grub, Tan Chwee Huat, Kwan Kuen-Chor and George H. Rott, eds., East Asia: Dimensions of international business (Prentice-Hall of Australia, Sydney) 45-55.

Choi, Sang-Rim and Adrian E. Tschoegl, 1984, Bank employment in the world's largest banks: An update, Journal of Money, Credit, and Banking 16, no. 3, 359-362.

Chrystal, K. Alec, 1984, International banking facilities, Federal Reserve Bank of St. Louis, Economic Review 66, no. 4, 5-11.

Francis, Carlene $Y ., 1985$, The offshore banking sector in the Bahamas, Social and Economic Studies 34, no. 4, 91-110.

Johnson, Harry G., 1976, Panama as a regional financial center: A preliminary analysis of development contribution, Economic Development and Cultural Change 24, no. 2, 261-286.

Kaufman, George G., 1970, Bank employment: A cross-section analysis of the world's largest banks, Journal of Money, Credit, and Banking 2, no. 1, 101-111.

Lessard, Donald R. and Adrian E. Tschoegl, 1985, Panama's International Banking Center: Where does it stand and what can be done to insure its continued viability and increase its contributions to the Panamanian economy?, Working paper 1985-2 (International Business Banking Institute, University of Miami, Coral Gables, FL).

McCarthy, Ian, 1979, Offshore banking centers: Benefits and costs, Finance and Development, Dec., 45-48.

Short, Brock K., 1971, Bank employment in the world's largest banks, Iournal of Money, Credit. and Banking 3, no. 3, 709-711. 
Short, Brock K., 1977, A note on employment in Thai commercial banks, Malayan Economic Review 22, 62-63.

Terrell, Henry S. and Rodney H. Mills, 1983, International banking facilities and the Eurodollar market, Staff study 124, Aug. (Board of Governors of the Federal Reserve System, Washington, DC).

Trivoli, George W., 1981, The international banking facility threat or opportunity, The Bankers Magazine 164, no. 5, 12-16.

Whitlam, Nicholas, Chair, 1984, Report of the committee established by the Premier of New South Wales to report on the steps necessary to establish offshore banking activity in Australia, with particular reference to Sydney, Unpublished report. 